\title{
Contested Spaces, Contested Memories: Images of Post-Soviet Military Bases in Reunified Germany

\author{
Christoph Lorke
}

DOI: 10.21104/CL.2019.4.02

\begin{abstract}
When it was decided in the late summer of 1990 that the Soviet troops would withdraw completely from the recently unified Federal Republic of Germany by the end of 1994, the modalities and logistical details of the withdrawal of people and material soon developed into a heated political issue. The 'Russians' and the spaces they had occupied since the end of the Second World War quickly became important topics in the newly unified German society, and their impact during this highly dynamic and confusing period cannot be underestimated. In particular, the German mass media played an immensely important role in the public and symbolic imagination of these perpetual 'strangers' and their spaces. In some parts of the media, these spaces were portrayed as requiring an urgent transformation so that they could become 'German' again. Via the social images of the post-Soviet military bases, this article discusses the immediate and longterm consequences of attributions and categorizations of the 'Russian' past and argues that those contested images also allow insights into the functioning of society's self-understanding discourses in reunified Germany.
\end{abstract}

\section{Key words}

appropriation, foreign military presence, Germany, identity, legacy, military heritage, post-Cold War, social images, Soviet Army, transformation

\section{Contact}

Christoph Lorke, PD Dr., Department of History, Westfälische Wilhelms University Münster, Historisches Seminar, Domplatz 20-22, 48143 Münster, Germany, e-mail: christoph.lorke@uni-muenster.de.

\section{Jak citovat / How to cite}

Lorke, Christoph. (2019). Contested Spaces, Contested Memories: Images of Post-Soviet Military Bases in Reunified Germany. Český lid 106, 439-461. doi:http://dx.doi.org/10.21104/CL.2019.4.02 
According to Article 4 of the Treaty on the Final Settlement with Respect to Germany (Two Plus Four Treaty; adopted on September 12, 1990, which entered into force on March 15, 1991), the Soviet Union was obliged to withdraw the troops it had stationed on the territory of the German Democratic Republic (GDR, or East Germany) within four years. The treaty articulated an ambitious goal, however, which reached far beyond the infrastructural and logistical issues associated with the withdrawal of troops.

More importantly, this contract seemed to clarify an important question which had arisen in the popular imagination and in the public media since the summer of 1990, namely: 'What to do with the Russians?', as the cover page of the news magazine Der Spiegel posed on July 16, 1990. After the Second World War, the Soviet Army's troops in East Germany were referred to as the Group of Soviet Forces in Germany (1954-1988) and, later, the Western Group of Forces (1988-1994). The force comprised 550,000 people, of whom approximately one third were civilians, based in more than one thousand locations all over East Germany. This concentration of troops underlines Germany's role as a strategic outpost at the western end of the Iron Curtain and, thus, as an immensely important bulwark for reinforcing the Soviet sphere of power and military security. By the end of the 1980s Soviet troops occupied 777 barracks at 276 locations within the territory of the former GDR, from Dranske (Isle of Rügen) in the north to Schöneck (Vogtland) in the south, and from Wachstedt (Eichsfeld) in the west to Kietz (OderRiver) in the east. The training grounds built in Germany covered an area the size of the federal state of Saarland. Most of the locations were situated in the area of the present-day state of Brandenburg, where the supreme command of the Group of Soviet Forces in Germany was located, and specifically in Wünsdorf (Kowalczuk - Wolle 2010: 228; see also Lorke 2017). The extent of this infrastructure alone already indicates the logistical challenges associated with the withdrawal. On October 9, 1990, one week after the completion of German unification, a treaty was signed on the Conditions of the Limited Stay and the Modalities of the Planned Withdrawal of the Soviet Troops from the Territory of the Federal Republic of Germany (which entered into force October 12, 1990). This agreement significantly restricted previous legal rights and practices. For example, bans were enacted concerning the movement of troops on public roads, low-altitude flights, and flights on Sundays and on public holidays. The German Liaison Command to the Soviet Armed Forces represented the interests of the Federal Minister of Defence and reviewed the progress of these considerations; a 'Mixed Commission' was appointed to monitor compliance with the agreement and settle disputes 
(Burlakov 1994: 123). ${ }^{1}$ As a result, over 1,000 military objects and 15 large military training areas needed to be cleared and handed over to the German administration, and over 2 million tons of 'material and technical means'needed to be packed. This was a gigantic logistical undertaking (Lohmann 2010; Meißner 2016). On August 3, 1994, the largest relocation of troops during peacetime was finally realized - four months earlier than originally planned - and brought about an unprecedented demilitarization of land and property. However, as I will argue in this paper, the withdrawal was accompanied by signs of unrest, especially in the mass media, who, for their part, were in a process of 'discovery' after 1990... The Foreign Minister of the Soviet Union at the time, Eduard Shevardnadze, had called for a'withdrawal with dignity'during the Two Plus Four negotiations, but this was anything but self-evident (for context, see Lorke 2017). Some of those involved in the actual withdrawal viewed the process as 'almost peaceful and dignified', such as Hartmut Foertsch, the director of the liaison organization between the German and Russian armies (Foertsch 1995; see also Foertsch 1994). Others, like the ambassador and chairman of the German-Russian mixed commission in Bonn, saw it as a 'political and military success' and characterized the Russian withdrawal as melancholic, but not bitter; the mutual understanding of the 'peculiarities, sensitivities, and ways of thinking' of each side had grown in the years since 1990 (Duisberg 1994: 466-467; see also Grote 2016: 81). Behind these statements one can detect a rather affirmative assessment of the events of that time, especially when we examine the local negotiations, commemorative cultural dimensions, and contemporary reporting in the public media.

The way the topic was reported in the media and the imagery with which the locations of the events were portrayed had great military and symbolic importance. The media reports reached apexes in 1990 (the year

1 For more background information, see Mroß 2004: 20-36. See also the archival material in the Bundesarchiv, signature BW 55 - Deutsches Verbindungskommando. In February 1992 the German Liaison Command, which also managed an airspace coordination centre, set up a fund to support Russian soldiers and their families and provide medical assistance. In addition, there were retraining programmes and other accompanying measures. The central issue was certainly the interplay between the housing programme in the new/old homeland and the withdrawal of the troops. This was the starting point for constant conflicts, for example, about the use of weapons outside the properties. The question of cost is still discussed very differently today, that is, whether or not it was too high, as the reason for the relatively rapid withdrawal is still attributed to each side. On the Russian side, sacrifice and a gesture of good will are most frequently mentioned. As an example, see Terentjew 2016. 
the Two Plus Four Treaty was signed) and 1994 (the final year of the withdrawal). The impact of the press coverage about the modalities of the withdrawal in those years cannot be understated. These imaginations had a decisive influence on the popular perception of the Russian troops and their locations, as noted by Matwej Burlakov, the final Commander-inChief of the Western Group of Forces and the leader of the withdrawal. He criticized the many subjective and ambivalent reports about his units, and he rejected as 'gross slander' the reports about corruption, connections between the troops and the mafia, and arms smuggling. Another equally serious concern was the idea circulated in the press of a separate farewell ceremony for the Western forces and the Russian forces. ${ }^{2}$ In reaction to the 'bad press' of several negative reports in national newspapers, the Russian High Command became increasingly isolated (for examples, see Hénard 1994). A separate press office had been established previously, which was interested in more objective reporting and sought to improve cooperation between the press and the Government's information offices. Burlakov was accustomed to a completely different form of mass media communication in the closed societies of the GDR and the Soviet Union. As a result, he tried to improve the image of the Russian troops and infrastructure at press conferences and in interviews and meetings with representatives of the German media, in part by facilitating access to barracks and garrisons (Burlakov 1994: 49-50, 160). It seems obvious why Burlakov attributed such an important role to the media. The colonel general thought that the decision on the withdrawal should begin with the production of (new) historical narratives and the imprinting of collective forms of memory regarding the places occupied by Soviet/Russian troops in German contemporary history (for the relation between mass media and collective memory, see Zelizer - Tenenboim-Weinblatt 2014). It is likely that an important driving factor in Burlakov's frame of mind was a desire to retain control over how the military bases were interpreted in the public eye. The press was therefore of considerable importance, as will be examined more closely in this article. Contemporary reports from that time can be used to understand the symbolic modes of attribution and categorization as well as the linguistic and visual representations of social reality, or in short, 'social images' (Burrow 1924/25; Taylor 2004). Social images can act as microcosms of the production and reproduction of certain social circumstances. In terms of their importance in this article, social images, above all, refer to the visible and invisible, as well as reversing previous hierarchies, inequality and power relations, and iden-

2 The media sources accused by Burlakov of circulating this story include Berliner Morgenpost, Neue Zeit, and Märkische Allgemeine; Burlakov 1994: 21-22, 155-157. 
tities.Through their performativity, these images represent the result of the struggle for interpretative dominance over the 'appropriate' (i.e. socially accepted) classification, presentation, and performance of the social order. They highlight the social, discursive, and symbolic (re-)formation and (re-) configuration of heritage - and military heritage, in particular and its space and symbolic determination (Keller 2016).

The constant circulation of social images in the mass media involving the 'Russians' and their military bases as contested spaces could be regarded as a microcosm of the production and reproduction of existing cultural patterns of interpretation (see Volkov 2017). To this end, in this paper I evaluate press articles dealing with the communicative and symbolic handling of the barracks which were still occupied in the 'transition phase' of the early 'unification society' (Vereinigungsgesellschaft; see Großbölting - Lorke 2017) and the military legacies in the first decade after reunification. These articles illustrate the diverse and highly contested legacies of the Cold War era and their impact in the present day. They also refer to symbolic hierarchies and shared - as well as partitioned memories, emotions, and identities. Therefore, in this paper I systematically evaluate ${ }^{3}$ the hegemonic social images which were widely circulated in the mass media in the period of transition during the 1990s Although this is certainly not the only mode of dealing with the historical past by the mass media, it is probably the most visible. Extending the period of investigation to the year 2000 makes it possible to showcase different aspects in the process of adapting post-Cold War military zones via certain hegemonic social images. This access makes it possible to illustrate the military sites as historically changeable areas for negotiating both popular imaginations of the past, as well as the present and the future. The period under study also offers new insights into the process of the withdrawal, as it can be characterized as a highly dynamic phase regarding the nation concept, identity, the politics of remembrance, and the relation-

3 The investigation is based on 89 contemporary articles. Therefore, nationwide east and west German newspapers and journals have been systematically evaluated (Frankfurter Allgemeine Zeitung, Süddeutsche Zeitung, Spiegel, Zeit, Welt, Neues Deutschland). To supplement the research, additional research was carried out in the press archives of the Bundestag (https://www.bundestag. de/dokumente/pressedokumentation) and in two party archives: Archiv für Christlich-Demokratische Politik (ACDP) / Konrad-Adenauer-Stiftung St. Augustin and Archiv der sozialen Demokratie (AdsD) in Bonn. These articles have been supplemented by some accounts from the local media in places where larger garrisons of troops were stationed (e.g. Berliner Morgenpost, Berliner Zeitung, Magdeburger Volksstimme, Sächsische Zeitung, Stendaler Volksstimme, Schweriner Volkszeitung). 
ship between 'German' and 'foreign' (Götz 2017; for the relation between cultural heritage and war, see Sørensen - Viejo-Rose 2015; Bennett 2017). The following sections focus on four aisles overlapping in time and hardly separable from each other resulting from the evaluation of the material. The social images discussed here reveal the often contradictory and complex contemporary narratives about the Russian withdrawal, the legacy of the Soviet/Russian troops, and the present and future of their military legacies (Demski 2017).

\section{Attributions of Foreignness: Symbolic and Material Refusals of Unwelcome Neighbours}

From a cultural perspective, dealing with the Soviets or Russians was impossible for many Germans even before the collapse of the GDR, but even more so after. Many of its citizens had more or less resigned themselves to sharing a neighbourhood with the Soviet Army for several decades. Although individual relationships did exist between members of the Soviet troops and the population, recent research speaks to a 'prevented friendship between nations' (Satjukow 2005: 24; for individual relationships between Soviet troops and German neighbours and its legacies, see for example Lorke 2017). After 1989, however, new events were to take place. The Soviet past had suddenly become part of a lost history. The perception of cultural differences and the specific conditions for where troops could be stationed - including the strict distance and isolation from the Germans - were decisive factors in how the soldiers were perceived in the period after 1989/90. While before this key year the official framing was that of a German-Soviet 'friendship', in fact, it was often no more than a clichéd official phrase or was, at best, limited to the officer corps. The term 'friends' was ironically ambiguous and influenced the political caesura. Thus, after the fall of the Berlin Wall in 1989, local Germans avoided inviting village mayors to celebrate friendship rituals together (Schulze 2000: 598; Müller 2007 for media examples, see Habbe 1993 and N.N. 1994a).

Over time, popular opinion on German-Soviet unity shifted from a feeling of euphoria to one of annoyance. In a survey conducted in late 1990 by the Institute for Social Research and Social Policy on behalf of the Federal Ministry of Labour and Social Affairs, 205 people were asked whether they were bothered in their everyday lives by the presence of Soviet soldiers and their families. Although at the time only 5.9 percent answered 'yes', a clear aversion emerged when the question was more openended. In these instances, special mention was made about the noise from 
Russian aircraft and military vehicles; ruthless drivers; commotion from drunken soldiers and their families; the neglected state of their homes; the impertinence of women; their general smell, arrogance, and laziness; the buying and hoarding of goods from the shops (whereas, in contrast, less well-off soldiers were referred to as 'poor pigs'); burglary; and reports of crime (Breuer 1990: 41). These perceptions not only suggest the reproduction of traditional, negative anti-Russian stereotypes, but were also, as will be shown later, taken up by contemporary media - sometimes subtly, sometimes more directly. Furthermore, the accumulated aggression against the Russians led to vandalism and promoted violence. Local attacks on soldiers, their families, and their children were not uncommon. In addition, anti-Soviet slogans like 'Russians out!' were painted on the walls of barracks. There were reports of locals throwing stones at military cars, skinheads attacking Russian soldiers in Neuruppin, or fights between youths and soldiers in Jüterbog and elsewhere (N.N. 1990a). A barracks in which 30 soldiers were sleeping was set on fire, although no one was injured in the arson attack (Schulze 2000: 631; N.N. 1994b). A total of 163 incidents were recorded in 1990, and this number nearly doubled in 1991. In 1992, more than 1,000 incidents were registered. According to Burlakov, the German press was not blameless for these events, as its reports about thousands of Russians roaming the German forests and selling weapons and ammunition undoubtedly stoked popular anger. In view of the coup against Gorbachev in the Soviet Union, it was also unclear how the troops would behave. The collapse of the Soviet Union and the increasing uncertainties on both sides made the withdrawal even more difficult. The fact that the troops were obliged to adopt a defensive stance had apparently exacerbated the difficult withdrawal. A total of 23 Russian citizens lost their lives in this period (Burlakov 1994: 57, 155).

Given this tense situation, it was not particularly helpful that the Deputy Mayor of Wünsdorf, where the troops' headquarters were located, had defended actions 'against the Russians'. Her statements were meant to defend the local shopping mall against 'Soviets hungry for any available goods' ${ }^{4}$ In addition, envy can be seen again and again. An article in Der Spiegel from July 16, 1990 stated, not surprisingly, 'The Russians will be the first to leave'. In the same article, the Mayor of Wünsdorf was quoted as saying that a Soviet officer with 1,000 marks owned considerably more 'than our people', while a resident called the soldiers 'dirty sacks that don't work all day' (N.N. 1990b). In addition, protests in individual cities over the continued use of land as training grounds for the Bundeswehr (German army) were not conducive to improving the image of the 'for-

4 'Impressum', Spiegel, July 16, 1990. 
eign' troops and their locations. In some cases, entire regions were embroiled in social unrest, for example in the Wittstock-Ruppiner-Heide or in the Colbitz-Letzlinger Heide (N.N. 1994c).

How can we interpret these social images? Especially in a time marked by uncertainty and perceived discrimination, the feeling of being threatened by foreign 'occupants' and the interpretation of non-German ethnic groups as 'foreign' had a significant influence. The role of the Soviets in the GDR and their invented 'friendship' were now all the more strongly contested and reversed. The 'Russians' remained 'foreign friends' in the GDR's culture of mistrust (Behrends 2003: 98). Anti-communist resentment took its course when the GDR came to an end, with mass media contributing a direct, albeit often presumably unintended, share to the bitter feelings of the day. As will be shown in the following sections, this hard-to-conceal antipathy could also be found also in other areas.

\section{Alienation: Sex, Drugs, and Crime}

There was a great deal of local interest in the inner life and future of the barracks and other former Soviet properties, not least because of the numerous myths and rumours which had developed as a result of their complete isolation from the rest of GDR society. After all, the areas used by the troops amounted to at least 6 percent of the total territory of the GDR (Kowalczuk - Wolle 2010: 221). After the Russian withdrawal, the civilian inhabitants often found the barracks in a state of abandonment or ruin (Mara 1996; Proebst 1997) with dilapidated facilities in extremely poor condition, and they encountered piles of rubbish everywhere (Busse 2012).

The Wünsdorf Arsenal is literally a mess: there are tens of million packs of chewing gum stored next to vast quantities of yoghurt with an expired expiry date; 14,000 pairs of cloth shoes from Indonesia have been on the shelves for a long time; and next to them are piles of cartons full of Thuringian Christmas tree decorations; 2000 carpets and 120,000 video cassettes suck themselves full of cold humidity; and plastic jackets hang next to ankle-length mink coats. [...] Some of the deliveries landing in Wünsdorf obviously disappear into the internal black market of the military. On the paths around the warehouses, there are a noticeably large number of uniforms with crates and parcels along the way. But the expensive goods probably go to more lucrative markets. [N.N. (1990d), translated by the author]

On the one hand, a concern for the cost of refurbishing the properties was raised repeatedly, but on the other hand, the possible dangers of leav- 
ing the properties in such a state were also pointed out. Local politicians and the media urgently warned people against entering the facilities out of fear of potential fatal accidents, especially involving children (N.N. 1992a). This, in turn, fostered resentment among the population and confirmed the suspicion that the soldiers had taken with them everything 'which hadn't been nailed down' (see the section on marketization; Kowalczuk - Wolle 2010: 223).

Above all else, the dimension of violence was taken up by the public and exploited hundreds of times in the media. Throughout this period, the Federal Criminal Police Office recorded 30 crimes each week involving Russian soldiers. Much remained hidden from the public, such as the case of an 18-year-old Russian soldier who was murdered in Wittstock, presumably by one of his own comrades (N.N. 1991a; Mroß 2004: 76). The list of reports was long and sordid. Some covered a variety of crimes, such as the armed and drunken soldiers from a garrison in Neustrelitz who, on their way to steal several cars, killed a policeman on patrol. Others detailed instances of prostitution, arms trading (Burlakov 1994: 156), and unexplained deaths, such as a young German motorcyclist killed in April 1992 or shots fired at people seeking asylum from the former Soviet Union (N.N. 1992a; N.N. 1992c). Even before reunification, different media show that the social climate had become more chaotic in general, which, in turn, led to results which the press used to foment further unrest (N.N. 1993a). Added to this were the uncertain whereabouts of 80,000 tons of ammunition and rumours of ill-treatment of soldiers by officers, as well as of illegal arms trading (N.N. 1994d; Wendt 1994). Der Spiegel reported that the barracks became 'medieval torture rooms' at night, where, according to its speculation, abuse, rape, and sexual violence all took place (N.N. 1991a). One article referenced illegal businesses and 'bodies in the lake' (N.N. 1994e). ${ }^{5}$ A series of bizarre murders committed by pimps in the area around Berlin contributed to the media hype, and the media accused Russian officers of coordinating these criminal rings (N.N. 1991b). If true, the officers would have been involved in activity worth billions of marks from robbery and smuggling, which is why Wünsdorf was described as a 'metastasis of corruption' (N.N. 1992d) or as a 'sewer' (Habbe 1993), while other newspapers detailed a 'long list of sins committed by the Western Group of Forces' (N.N. 1994f). Still others reported on the desolate state of the Russian Army in a crisis-ridden country. The Deputy Defence Minister, Boris Gromov, even spoke of an 'army soiled by corruption' (N.N. 1994g).

5 See also the documentation in the Bundesarchiv, BW 55/50, Presseausschnittsammlung zu Ereignissen in den Gemeinden Lückenwalde, Jüterbog, Zossen und Königs Wusterhausen; BW 55/159, Vol. 5; BW 55/146. 
Books also contributed to the nurturing of this image. Andrej Illesch's book, Die roten Paten ('The Red Godfathers') promoted an image of drugs, prostitution, contract killers, the shadow economy, and mafia structures, and it was also intended to have a major influence on the perception of the troops stationed in Germany (Illesch 1992). Other works became veritable best-sellers in the German book market. Together with their frightening, dark, and sometimes voyeuristic reporting, they were apparently precisely tailored to the tastes of East and West German audiences. A period full of breaks and reorientations, perceived by many as confusing and chaotic, created a breeding ground for such narratives. In turn, these narratives may have influenced the perception of the presence of Russian soldiers (e.g. Witaljew 1990; Waksberg 1991; Vitaliev 1994; Roth 1996; Goworuchin 1996; Schmid 1996; Lallemand 1997; Lesnik - Blanc 1997). Information and details from these books were repeated later in in many media articles, and the popular conceptions they ignited were able to thrive in this atmosphere. Added to this was an increasing uncertainty on the Russian side, framed against the background of the collapse of the Soviet Empire and the central topos of the corresponding social and economic upheaval. The number of reported Russian deserters (estimated at over $1,200)$ mentioned in various articles - and the speculation associated with them - certainly caused discomfort among some readers. In short, the deserters stood for uncontrollability and chaos. Even though Burlakov considered these men to be criminals, both German and international law had to be observed when punishing them, leading to complications in individual cases (Mroß 2004: 61; Burlakov 1994: 39-40). However, the feared wave of asylum applicants failed to materialize. Only 252 applications were submitted in total, which was due to both the draconian measures taken against the soldiers and Germany's strict legislation regarding asylum (Bange 2016: 51; Duisberg 1994: 467; for a contemporary example, see N.N. 1990c).

\section{Ecological Emergencies: The 'Russians' as Polluters}

Contemporary reporting and its social imaginations also reflects on one main issue which was particularly important at that time: ecology. Both Mecklenburg-Western Pomerania and Saxony-Anhalt rejected the federal government's offer to take over the former Soviet properties free of charge due to the expected high cost of rehabilitation (N.N. 1991b; N.N. 1991c; N.N. 1994h; N.N. 1997a). 
When the Soviet troops withdraw from Deutsch-Ost, they leave behind an ecological emergency area. The occupying troops have maltreated the country for decades without taking environmental protection into consideration. Soils are contaminated with oil, many rivers and lakes ruined. The extent of the disaster is not yet clear. [N.N. (1990a), translated by the author]

The extent of the ecological damage was considerable, and it was suspected that poisonous chemicals had been disposed of improperly. In addition, carelessness on the part of the Russian leadership was noted. The Russians' response came too late (N.N. 1990e). Locally, as in Magdeburg, there was talk of 'environmental bombs' and 'Soviet scrap' (N.N. 1991c; N.N. 1992e). In countless letters to the editor and in articles, local residents protested against the noise, illegal garbage dumping, and shell splinters and cannon thunder; these complaints - and, simply put, fear were expressed with an unprecedented openness. ${ }^{6}$

In terms of environmental issues, differences in perception quickly became apparent. According to Burlakov, the Russian efforts towards the re-cultivation of arable land had hardly been appreciated in the German press, and instead the media had spread 'horror stories'. For example, there was talk of 'tank cemeteries' and other leftovers of the Soviet presence, much of which were not actually attributable to the Russians (Burlakov 1994: 154). German representatives, such as those from an ecological activist movement in Urstromtal, complained that the Soviets had no knowledge about environmental issues. They would have to discard their 'occupation power ideology' and develop a real awareness of the problem, or else popular approval would continue to dwindle - precisely because, in the opinion of some commentators, the Russian troops would leave behind them 'lunar landscapes' (N.N. 1992f; N.N. 1994i).

In any case, the elimination and handling of environmental damage was an explosive and long-lasting issue. Overall, evaluating the environmental impact of the Soviet occupation reveals considerable differences in perceptions on both sides (Meißner 2016: 61-62). In 1994 the German Association of Towns and Municipalities declared the topic, in view of the anticipated costs, to be a 'national task' (N.N. 1994j). In response, some commentators referenced images of a 'ticking time bomb',

6 See the Bundesarchiv, BW 55/19. Here, violations, incidents, complaints, petitions, and a catalogue of measures to reduce aircraft noise and environmental pollution are catalogued. After the crash of a Soviet MIG 27 fighter plane, protests were held in the Baruth area, but after the mediation of the Western Group of Forces and the commune they ended peacefully. 
a 'plague', or just a 'source of danger' (Flocken 1994; N.N. 1994k; N.N. 1995a; N.N. 1995b), while others declared it an 'ecological emergency' (Teske 1995). But other issues were also at the centre of debate. These included the preservation of cultural landscapes, the protection of nature and the countryside, the valuation of former Soviet properties (i.e. the determination of the quality and the sale value in line with market conditions), and the elimination of military waste and pollution from explosive ordnance. In addition, there were questions and opportunities regarding structural change and the establishment of centres for technology and innovation. Contemporary estimates put the cost of removing military and ecological contamination at about 100 billion marks, and the work was estimated to take 15 years to complete (Kratz 2003). Much higher numbers were also discussed. This is why in the following years, the narratives fluctuated between the dramatization, excessive demands, and fears about the ecological future (N.N. 1994l; Mara 1995; N.N. 1996a; N.N. 1996b; N.N. 1997b) and - to a much lesser extent - reassurance (N.N. 1995c).

\section{Marketization: Porn Cassettes as Barter Goods}

The officer has just laid the foundation stone for survival in his homeland: twenty marks for a porn movie that can be copied to blank tapes and sold for ten times more money at home for each copy. It can also be used to organize private cinema evenings, admission to a hot show for at least ten rubles per capita - all in all a promising investment for the future. [N.N. (1990e), translated by the author]

While the former citizens of the GDR were in a consumer frenzy, Russian soldiers were facing an undreamt-of future. This identity crisis - but also the first contact with Western money and Western goods - was taken up by the mass media (N.N. 1990b). The visual exoticization of Western goods was the order of the day: Western prosperity, alcohol, cigarettes, televisions, and bribes to obtain a work permit or (for women) to obtain a job (hence the accusing and understanding tone in Fuhrmann 1991). The situation was clearly reflected in a report in Der Spiegel on November 2, 1992: 'porn cassettes as barter goods', electronics, Western cigars, and canned beer were being exchanged for weapons and caviar. The soldiers had little time to learn how to handle appropriately the newly available money, and capitalism 'corroded' their morale 'overnight'. A wife of a Soviet officer praised the paradise-like conditions and stated that she did not know what to buy first (N.N. 1991a; N.N. 1992g). 
These media perspectives reveal a judgement that these behaviours were somehow premodern, and that the people were unaccustomed to a capitalistic way of life. Other articles described the withdrawal as an expulsion from paradise and reported on a flourishing black-market trade in, for example, weapons, gasoline, and military accessories (N.N. 1990f). Contemporary reporting also commented on an increase in poverty, referencing people begging for cigarettes or money, illegally logging, searching through rubbish for uneaten food, or stealing potatoes or sheep from the fields to supplement their diet. The fact that the theft of handbags drastically increased in the vicinity of military locations fit easily within this picture (N.N. 1990f). This reporting was supported by the use of derogatory terms such as 'Russian bazaar', which referred to a form of haggling which was perceived to be 'non-German' (Habbe 1993). All this reflected the abyss between the concepts of 'over here'(Germany) and 'over there' (Russia), but it also reinforced the increasing criticism of West German traders who had humiliated the Russians by exaggerating the costs of goods and services. Because horrendous prices were being demanded for even simple items like fruit, a Kafkaesque world appeared on the black market: the proud victors of the past were now imagined as beggars (N.N. 1990f). According to the media, the upheaval between 1989 and 1991 had united the worldview of the Russian soldiers against Germany and towards their homeland without a future. This refers to one last dimension of the reporting in contemporary sources (N.N. 1991a).

\section{Conclusions and Future Directions}

The farewell and the imaginations of it were also contradictory. Thuringia was the first federal state to be completely cleared of troops, with the withdrawal finishing by the end of 1992. At farewell ceremonies here (N.N. 1992h; N.N. 1992i and, with a sad undertone, N.N. 1994m), there was little sadness. As the mayor of Dresden, Herbert Wagner, stated at the time, joy prevailed - at least on the German side (Satjukow 2007: 15). The withdrawal was accompanied by several 'open days' to ensure transparency and overcome insecurity, the first of which was held in February 1991 in 23 garrisons (Burlakov 1994: 49). In Stendal, hundreds of people came to say goodbye to the soldiers at the Ostbahnhof. Remembrance gifts were exchanged, the atmosphere was described as warm and honourable, and the troops left Germany accompanied by both laughter and tears (N.N. 1991e). The local farewell ceremonies were a stage for the display of cheerfulness (N.N. 1991f; N.N. 1993b; Nawrocki 1994) and, 
thus, should be understood as a revitalization of the 'friendship' narrative (though probably not shared by everybody). ${ }^{7}$

\begin{abstract}
Already at the atmospheric concert of the Russian Wünsdorf Orchestra there were many attentive listeners. Among them was Rudolf Aubner (66) from Schwerin, who looks forward to the troop withdrawal with a tearful eye. 'We have had good friends for many years. They are now going back to Sverdlovsk. We also lived very well together with Soviet families in one house for two years.' [Fischer (1993), translated by the author]
\end{abstract}

But the ceremonies were not just a breath of fresh air; sometimes compassion was expressed by the media, as well. Some reporters regularly stressed the uncertain future and expressed empathy with those who had returned as members of an 'army on demand'. Their presumed unwelcomeness at home - this was a central image in many articles - and the feeling of not having left the country victorious (Peters 1992; strikingly critical is Spar 1993; N.N. 1993b) made the 'fear of home' an important topos (Schwellen 1991). Moreover, failures of the German authorities were denounced, such as their toleration of right-wing radical activities in the vicinity of the barracks (Hénard 1994). Also, there was a great deal of astonishment at the idea of organizing the farewell ceremony for the Russian troops as a singular event in the National Theater in Weimar, rather than as a collective event with the British, American, and French military forces in Berlin, because, above all, Chancellor Helmut Kohl was against a 'joint and equal leaving of all Allied forces in Germany'. Finally, the official farewell ceremony in Berlin was held in the summer of 1994. But even the highly symbolic, joint laying of a wreath at the Soviet memorial in Berlin-Treptow and the emotional singing of the specially composed song Lebe wohl, Deutschland, wir reichen dir die Hand ('Goodbye Germany, We Reach Out Our Hands') could not hide the fact that the day was experienced and remembered as a 'second-class' departure (Kaiser - Herrmann 2010: 185-186; for contemporary comments, see amongst others N.N. 1994n, and not least the strong criticism of Helig 1994).

For many spectators, one of the highlights of these years was an event which represented the overcoming of the German division: namely, the withdrawal of Russian soldiers from the Brocken, the second-highest mountain in East Germany and a symbolic location situated directly on the border between East and West Germany (N.N. 1999). There was great

7 For examples of farewell ceremonies held for the Russian troops, programmes, and programme proposals, see the Bundesarchiv, BW 55/8. 
optimism that the former Soviet military properties would be put to new use: local politicians hoped to attract solvent investors and to use the properties as government quarters or as centres for trade and services. Other focuses of attention were nature conservation, tourism, and the construction of new homes. All these hopes, however, were never fulfilled to the desired extent (Krauß 1995; N.N. 1995d; N.N. 1998a; see also the detailed notes in Kratz 2003). There were numerous attempts to revive the properties for civilian purposes, and some of these were successful (N.N. 1995e; N.N. 1996c; N.N. 1997c; N.N. 1997d; N.N. 1997e; N.N. 1997f). However, the properties also suffered from vandalism and accelerated decay (Inhoffen 1995), as well as 'crooked deals' (N.N. 1995f; N.N. 1996d). In cases where the properties were already deemed to be 'creepy places', their hope of ever being rehabilitated grew increasingly dismal (Woldt 1996; N.N. 1997g; N.N. 1997h; N.N. 1998b; Pergande 1999). It is not surprising, therefore, that at the end of the 1990s many commentators still spoke of a 'difficult legacy' (N.N. 1997i). At the same time, and probably in response to this, myths began to form about the formerly 'forbidden cities', and these myths were used in turn to attract more tourists to the region (Saft 1994; N.N. 1997j).

As the prior analysis of social images has shown, the withdrawal of the Russian armed forces can be understood as a barometer of the sensitivities of the contested and 'unification society'. In this society, the negotiation of memory was a central component: What was the GDR? How was it to be 'correctly' remembered? and What place should it occupy in the collective memory in the future (Meyen 2013)? Citizens in East and West Germany had had completely different experiences, knowledge, and attitudes towards the Soviet soldiers before 1989/94, but after 1990 the media narratives quickly turned into quite catchy, almost monotonous master stories about "the Russians" - only a few articles in the New Germany made a remarkable, yet hardly surprising exception. In the GDR and, later, in East Germany, the Soviets/Russians were also a part of their own past (which explains the "close" coverage in East German local newspapers), while in the West the reports were less emotional and more impartial. Here and there, however, anti-communist resentments were mixed into the reports, sometimes as a continuation of earlier perspectives, and at other times as an expression of the new freedom of expression (Poretschkin 1994). In the new 'unification society' many East German citizens simply had other problems, including unemployment, fear of the future, and processes of social decline (e.g. the city of Eberswalde, see Wernicke 1991). What was regarded as 'German' underwent a massive reinterpretation in the course of a comprehensive symbolic devaluation, which affected many places, 
while what was regarded as 'foreign' - whether internationally active companies, West German consultants, or migrants such as asylum seekers from the Balkans or from outside Europe - was perceived as a threat. As the analysis has shown, the collapse and unpredictable experience of foreignness also influenced the perception of Russian soldiers. There are various reasons for the rejection faced by Russian soldiers. However, the joyous frenzy of the unification East and West Germany in 1990 was central, decisively determining the redefinition of what was perceived as 'foreign' and partly explaining the return to traditional clichés and motives for rejection (Broszinsky-Schwabe 1990). In addition to such diachronies, it is, above all, the transnational, comparative perspectives on such transformations and continuities in the interpretations of the 'foreign' that would be particularly interesting questions for further research.

November 2019

\section{References}

Bange, Oliver. 2016. Die Sicherheitspolitik Moskaus und der Stationierungsalltag in der DDR. Vorgeschichte und Beginn des Abzugs von 1983 bis 1993. In: Steinberg, Detlev (ed.): Der Abzug. Die letzten fahre der russischen Truppen in Deutschland. Eine fotografische Dokumentation. Berlin: Links: 37-55.

Behrends, Jan C. 2003. Sowjetische 'Freunde' und fremde 'Russen'. Deutsch-sowjetische Freundschaft zwischen Ideologie und Alltag (1949-1990). In: Behrends, Jan C. - Lindenberger, Thomas - Poutrus, Patrice G. (eds.): Fremde und Fremd-Sein in der DDR. Zu historischen Ursachen der Fremdenfeindlichkeit in Ostdeutschland. Berlin: Metropol: 75-100. Bennett, Luke (ed.). 2017. In the Ruins of the Cold War Bunker. Affect, Materiality and Meaning Making. London: Rowman \& Littlefield International. Breuer, Wilhelm. 1990. Ausländerfeindlichkeit in der ehemaligen DDR. Studie zu Ursachen, Umfang und Auswirkungen von Ausländerfeindlichkeit im Gebiet der ehemaligen DDR und zu den Möglichkeiten ihrer Überwindung. Köln: ISG.

Broszinsky-Schwabe, Edith. 1990. Die DDR-Bürger im Umgang mit "Fremden" - Versuch einer Bilanz der Voraussetzung für ein Leben in einer multikulturellen Welt. In: Kleff, Sanem - Broszinsky-Schwabe, Albert - Marburger, Karsten (eds.): BRD - DDR: Alte und neue Rassismen im Zuge der deutsch-deutschen Einigung. Frankfurt a.M.: Verlag für Interkulturelle Kommunikation: 18-44. 
Burlakov, Matwej P. 1994. Wir verabschieden uns als Freunde. Der Abzug Aufzeichnungen des Oberkommandierenden der Westruppe der sowejetischen Streitkräfte. Bonn: InnoVatio-Verlag.

Burrow, Trigant. (1924/25). Social Images versus Reality. Fournal of Abnormal and Social Psychology 19: 230-235.

Busse, Daniel. 2012. Die Kasernenanlagen der Selauer Straße. Weißenfels: Arps. Demski, Dagnosław. 2017. Values, Substantiality, and Passage of Time: Representations and Reinterpretations of Military Heritage. Folklore: Electronic Fournal of Folklore 70: 171-192.

Duisberg, Claus J. 1994. Der Abzug der russischen Truppen aus Deutschland. Eine politische und militärische Erfolgsbilanz. Europa-Archiv 16: 461-469.

Fischer, K. 1993. Mit flotten Klängen in die Heimat zurück. Schweriner Volkszeitung, April 29.

Flocken, J. v. 1994. Russische Altlasten ticken in Deutschland. Berliner Morgenpost, 15 October.

Foertsch, Hartmut. 1994. Der Abzug russischer Truppen aus Deutschland. 'Keiner sagt: Jungs, kommt bald wieder'. Europäische Sicherheit 43, 3: 125-127.

Foertsch, Hartmut. 1995. Der Abzug der russischen Streitkräfte aus Deutschland. In: Thoß, Bruno (ed.): Vom Kalten Krieg zur deutschen Einheit. Analysen und Zeitzeugenberichte zur deutschen Militärgeschichte 1945 bis 1995. München: Oldenbourg: 463-471.

Fuhrmann, A. 1991. Garnison Wünsdorf. Zerrissen ist die russische Seele. Zeit, 4 January.

Grote, O. Freiherr. 2016. Die Westgruppe verlässt Deutschland. Der Abzug aus der Perspektive des Chefs des Stabes des Verbindungskommandos zur WGT. In: Steinberg, Detlev (ed.): Der Abzug. Die letzten Fahre der russischen Truppen in Deutschland. Eine fotografische Dokumentation. Berlin: Links: 74-89.

Götz, Irene. 2017. Die Wiederentdeckung des Nationalen nach 1989:

Die Suche nach neuen deutschen Selbstbildern und Identitäten. In: Großbölting, Thomas - Lorke, Christoph (eds.): Deutschland seit 1990: Wege in die Vereinigungsgesellschaft. Stuttgart: 51-73.

Goworuchin, Stanislaw. 1996. Moskau und die Mafia. Die große kriminelle Revolution. Berlin: Brandenburgisches Verlagshaus.

Großbölting, Thomas - Lorke, Christoph (eds.). 2017. Deutschland seit 1990: Wege in die Vereinigungsgesellschaft. Stuttgart: Franz Steiner.

Habbe, Christian. 1993. "Jottwehedeh und Zaun drum." Spiegel 2/1993: 86-91.

Helig, R. 1994. Abschied in zwei Klassen. Neues Deutschland, 31 August. 
Hénard, Jacqueline. 1994. Zwei Waffenbrüder aus feinem Porzellan. Von der Befindlichkeit russischer Soldaten in Deutschland. Frankfurter Allgemeine Zeitung, January 7.

Illesch, Andrej. 1992. Die roten Paten. Organisierte Verbrechen in der Sowjetunion. Reinbek: Rowohlt.

Inhoffen, Lisa. 1995. Wünsdorf '95: Von der verbotenen zur toten Stadt. General-Anzeiger, July 18.

Kaiser, Gerhard - Herrmann, Bernard. 2010. Vom Sperrgebiet zur Waldstadt. Die Geschichte der geheimen Kommandozentralen in Wünsdorf und Umgebung. Berlin: Links.

Keller, Reiner. 2016. Die symbolische Konstruktion von Räumen. Sozialkonstruktivistisch-diskursanalytische Perspektiven. In: Christmann, Gabriela B. (ed.): Zur kommunikativen Konstruktion von Räumen. Theoretische Konzepte und empirische Analysen. Wiesbaden: Springer: 55-78.

Kowalczuk, Ilko-Sascha - Wolle, Stefan. 2010. Roter Stern über Deutschland: sowjetische Truppen in der DDR. Berlin: Links.

Kratz, Walter. 2003. Konversion in Ostdeutschland. Die militärischen Liegenschaften der abgezogenen Sowjetischen Streitkräfte, ihre Erforschung, Sanierung und Umwidmung. Berlin: Trafo.

Krauß, M. 1995. "Zu Verschenken ist nichts." Die ersten WestgruppenLiegenschaften wurden verkauft. Berliner Zeitung, January 13.

Lallemand, Alain. 1997. Russische Mafia. Der Griff zur Macht. Das Netzwerk zwischen Moskau, Berlin und New York. München: Lichtenberg.

Lesnik, Renata - Blanc, Helene. 1997. Die neue Mafia. Gefahr aus dem Osten. München: Langen Müller.

Lohmann, Horst. 2010. Die Gruppe der Sorejetischen Streitkräfte in Deutschland 1945-1994. Ein historischer Abriss. Hoppegarten: Meißler, E.

Lorke, Christoph. 2017. After the End of "Little Moscow": Memories, (Re)Construction, and Appropriation of Space in Wünsdorf. Folklore: Electronic Fournal of Folklore 70: 19-50.

Mara, Michael. 1995. Altlasten, Preisnachlässe, teure Bewachung. Tagesspiegel, June 30.

Mara, Michael. 1996. Einstige GUS-Quartiere vergammeln. Tagesspiegel, June 11.

Meißner, Christoph. 2016. Der Abzug der Westgruppe aus der Perspektive deutscher Quellen. In: Steinberg, Detlev (ed.): Der Abzug. Die letzten Jahre der russischen Truppen in Deutschland. Eine fotografische Dokumentation. Berlin: Links: 56-73.

Meyen, Michael. 2013. "Wir haben freier gelebt." Die DDR im kollektiven Gedächtnis der Deutschen. Bielefeld: Transcript. 
Mroß, Bernhard. 2004. Sie gingen als Freunde... Der Abzug der Westgruppen der sowjetisch-russischen Truppen 1990-1994.

Harrislee: tek-digital service.

Müller, Christian T. 2005.“O’ Sowjetmensch!” Beziehungen von sowjetischen Streitkräften und DDR-Gesellschaft zwischen Ritual und Alltag. In: Müller, Christian T. - Poutrus, Patrice G. (eds.): Ankunft - Alltag - Ausreise. Migration und interkulturelle Begegnung in der DDR-Gesellschaft. Köln: Böhlau: 17-134.

N.N. 1990a. "Alles zerwühlt und kaputt." Spiegel 40/1990: 110-115.

N.N. 1990b. Die fliegen als erste raus. Spiegel 29/1990: 31-36.

N.N. 1990c. Delikate Fragen. Spiegel 32/1990: 34-36.

N.N. 1990d. Nerz und Matsch. Versorgungschaos bei der Roten Armee in Deutschland. Lebensmittel verderben, der Schwarzmarkt blüht. Spiegel 52/1990: 52-53.

N.N. 1990e. Kapitalismus am Kasernentor. Die demoralisierte Sowjetarmee wird von der D-Mark besiegt. Spiegel 37/1990: 68-77.

N.N. 1990f. "Gott mit Euch - Ungarn." Spiegel 29/1990: 122-125.

N.N. 1991a. "Den Rückzug nicht gelernt." Der Kapitalismus zersetzt die Moral der sowjetischen Streitkräfte in Deutschland. Spiegel 10/1991: 144-156.

N.N. 1991b. Mafia. Schweigen oder Sterben. Sowjetische Gangster liefern sich in Deutschland tödliche Konkurrenzkämpfe. Spiegel 45/1991: 126-133.

N.N. 1991c. Kanister, Munition, Panzer rosten im Biederitzer Busch. Kompetenzstreit zwischen Magistrat und Land über Sowjet-Schrott. Magdeburger Volksstimme, September 4.

N.N. 1991d. Russenwohnungen in kommunaler Hand. Magdeburger Volksstimme, September 13.

N.N. 1991e. Alles Gute, Stendal leuchtete von einem SPW. Stendaler Volksstimme, February 25.

N.N. 1991f. Armee setzt ihren Abzug planmäßig fort. Neues Deutschland, August 20.

N.N. 1992a. Do swidanija, towarisch. Sächsische Zeitung, February 25.

N.N. 1992b. Angreifer von GUS-Truppen erschossen. Süddeutsche Zeitung, April 13.

N.N. 1992c. Erneut Zwischenfall vor Kaserne der GUS-Truppen. Süddeutsche Zeitung, April 29.

N.N. 1992d. "Raub vor aller Augen." Spiegel 34/1992: 54-59.

N.N. 1992e. GUS-Areale: Größtes Umweltproblem. Berliner Morgenpost, December 16.

N.N. 1992f. Noch einmal volle Pulle. Spiegel 3/1992: 68-73. 
N.N. 1992g. Jaken und Suvenirs. Die abziehenden Truppen der GUS rücken ihre frei werdenden Wohnungen nicht heraus - sie vermarkten sie illegal. Spiegel 45/1992: 88-100.

N.N. 1992h. Mit den Freunden gab es nie wirklich Freundschaft. Neue Zeit, November 23.

N.N. 1992i. "Es ist kein Traum, es ist Wirklichkeit." Die Gardearmee der ehemaligen Sowjetunion ist aus Thüringen abgezogen. Frankfurter Allgemeine Zeitung, November 22.

N.N. 1993a. Der ungeordnete Abzug. GUS-Soldaten ohne Moral und Disziplin. Hamburger Abendblatt, January 13.

N.N. 1993b. Abschied. Schweriner Volkszeitung, April 29.

N.N. 1994a. Der Sowjetstern in der Pfütze. Der Brocken ist frei von Verkehr - bald kann man wieder bis ganz nach oben. Frankfurter Allgemeine Zeitung, April 2.

N.N. 1994b. Eisleben am Vorabend des Jahrestag zum Kriegsende. Neues Deutschland, May 9.

N.N. 1994c. Nach dem Abzug der russischen Truppen. Wohnungen ersetzen Kasernen. Süddeutsche Zeitung, July 6.

N.N. 1994d. Wo sind 81000 Tonnen Munition geblieben? Frankfurter Allgemeine Zeitung, February 16.

N.N. 1994e. Leichen im See. Immer öfter werden russische Offiziere bei illegalen Geschäften in Deutschland ertappt. Spiegel, January 24: 55-58.

N.N. 1994f. Schieber in Uniform. Schmuggel, Diebstahl, Waffenhandel. Das Sündenregister der Westgruppe. Die Woche, November 18.

N.N. 1994g. Meuterei der Empörten. Spiegel 36/1994: 146-147.

N.N. 1994h. 1700 ehemalige GUS-Wohnungen werden saniert. Berliner Zeitung, December 3.

N.N. 1994i. Die Soldaten gehen, die Schäden bleiben. Frankfurter Allgemeine Zeitung, April 7.

N.N. 1994j. Erblast der Militärs überfordert Kommunen. Tagesspiegel, November 10.

N.N. 1994k. "Munitionscocktails" und verseuchte Schrottplätze. Bonner Rundschau, November 7.

N.N. 1994l. Die Sanierung der Militärflächen überfordert Länder und Kommunen. Frankfurter Allgemeine Zeitung, November 15.

N.N. 1994m. Abschied vom russischen Oberkommando. Neues Deutschland, June 13.

N.N. 1994n. Getrennt feiern, gemeinsam abziehen. Ärger mit dem Abschied. Spiegel 20/1994: 20-28.

N.N. 1995a. Umweltbundesamt: Rote Armee hinterläßt 30000 verseuchte Flächen. Süddeutsche Zeitung, February 11. 
N.N. 1995b. Altlasten der Russen machen Land zu schaffen. Ehemalige Flugplätze sind die größten Gefahrenherde. Ostsee-Zeitung, August 15. N.N. 1995c. 5.700 Hektar oder 2,5 Prozent der gesamten Fläche galten nach einer Studie des Umweltministeriums als verseucht. Frankfurter Rundschau, December 16.

N.N. 1995d. Überreste des Kalten Krieges. Altlasten der sowjetischen Truppen auf ostdeutschen Böden. Frankfurter Allgemeine Zeitung, December 20.

N.N. 1995e. Wohnungen zum Schnäppchen-Preis. Ehemalige Russen-Immobilien werden verschenkt. Welt, November 25.

N.N. 1995f. Argwohn bei einem unwägbaren Geschäft. Sächsische Zeitung, December 2.

N.N. 1996a."Noch 100 Jahre leben mit Altlasten." Öko-Institut veranschlagt für Entsorgung aller russischen Truppengelände 3 Milliarden Mark. Berliner Morgenpost, October 28.

N.N. 1996b. Hohe Belastung mit Munition und Sonderabfällen. Frankfurter Allgemeine Zeitung, July 16.

N.N. 1996c. Einstige Garnisonsstadt wird immer ziviler. Berliner Zeitung, January 9 .

N.N. 1996d. Sachsen geht beim Verkauf des Militärgeländes der Russen voran. Frankfurter Allgemeine Zeitung, August 17.

N.N. 1997a. Die GUS-Truppen haben alles einfach vergraben. Das Trinkwasser in Ostdeutschland ist durch Giftstoffe von Militäranlagen vielerorts gefährdet. Stuttgarter Zeitung, October 7.

N.N. 1997b. Zuerst muß aufgeräumt werden, sonst ist die Gefahr zu groß. Berliner Morgenpost, December 11.

N.N. 1997c. Exerzierplätze werden zu neuen Wohnungen. 190 Hektar: Frankfurt/Oder meistert die Konversion. Welt, January 4.

N.N. 1997d. Russen-Kasernen zu Wohnungen. Zivile Wiederbelebungsversuche für ausgediente Militär-Liegenschaften treffen auf große Schwierigkeiten. Welt, January 25.

N.N. 1997e. Von der Militär- zur Bücherstadt. Berliner Morgenpost, March 6.

N.N. 1997f. Eine Bücherstadt auf alten Militärfläche. Berliner Morgenpost, May 19.

N.N. 1997g. Schwierige Verwertung von Kasernen. Altlasten hemmen den Verkauf. Berliner Zeitung, February 15.

N.N. 1997h. Tierparadies auf dem Konversionsgelände. Experten der TU Berlin wollen Mufflons, Bisons und Wildpferde ansiedeln. Berliner Morgenpost, March 22.

N.N. 1997i. Das schwere Erbe der Roten Armee. Berliner Morgenpost, August 19. 
N.N. 1997j. Neues Leben in der "Geisterstadt". Berliner Morgenpost, August 21.

N.N. 1998a. Im Zweifel zurück zur Natur. Süddeutsche Zeitung, September 9.

N.N. 1998b. Wünsdorf wird immer "ziviler". Ehemalige russische Kasernenstadt hat bald 1.000 Einwohner. Berliner Morgenpost, January 10.

N.N. 1999. Er steht. Er wankt. Er stürzt. Berliner Morgenpost, September 11.

Nawrocki, Josef. 1994. Abschied in Würde, Ankunft in Armut. Zeit, February 18.

Pergande, Frank. 1999. Noch mehr Wald für Brandenburg. Die Nutzung ehemaliger Militärgelände. Frankfurter Allgemeine Zeitung, April 26.

Peters, C. 1992. Eine Armee auf Abruf wartet verbittert auf den Marschbefehl. Ungeliebt hier und oft unerwünscht zuhause. Neue Ruhr Zeitung, December 12.

Poretschkin, A. 1994. Verständnislücken beim Abzug der Russen. Frankfurter Allgemeine Zeitung, September 17.

Proebst, P. 1997. Das teure Aufräumen nach 40 Jahren "Kaltem Krieg”. In Ostdeutschland sind noch große Flächen versucht. Saarbrücker Zeitung, September 26.

Roth, Jürgen. 1996. Die Russen-Mafia. Das gefährlichste Verbrechersyndikat der Welt. Hamburg: Rasch \& Röhring.

Saft, G. 1994. Wünsdorf - Die "verbotene Stadt" verbirgt noch viele Geheimnisse. Sächsische Zeitung, November 19.

Satjukow, Silke. (ed.). 2005. 'Die Russen kommen!' Erinnerungen an sowejetische Soldaten 1945-1992. Erfurt: Landeszentrale für politische Bildung Thüringen.

Satjukow, Silke. 2007. Besatzer: 'Die Russen' in Deutschland 1945-1994. Göttingen: Vandenhoeck \& Ruprecht.

Schmid, Ulrich. 1996. Gnadenlose Bruderschaften: Aufstieg der russischen Mafia. Paderborn: Schönigh.

Schulze, Henrik. 2000. Geschichte der Garnison füterbog 1864-1994 "Fammerbock". Osnabrück: Biblio-Verlag.

Schwellen, Michael. 1991. Lieber reich als ruhmreich. Zeit, July 5.

Spar, J. 1993. Sowjetoffiziere nach der Rückkehr aus Deutschland wie Fremde in der Heimat. Als Sieger fühlen sie sich nicht. Neues Deutschland, January 9.

Sørensen, Marie Louise S.- Viejo-Rose, Dacia (eds.). 2015. War and Cultural Heritage. Biographies of Place. Cambridge: Cambridge University Press.

Taylor, Charles. 2004. Modern Social Imaginaries. Duke: Duke University Press. 
Terentjew, Anton W. 2016. Der Abzug der Westgruppe der Truppen. Aus der Sicht eines russischen Generals. In: Steinberg, Detlev (ed.): Der Abzug. Die letzten Fahre der russischen Truppen in Deutschland. Eine fotografische Dokumentation. Berlin: Links: 37-55.

Teske, Knut. 1995. Schrott, Chaos und Verachtung - das Erbe der Besatzungsmacht. Die Westgruppe hinterließ in Ostdeutschland ein ökologisches Notstandsgebiet. Welt, September 5.

Vitaliev, Vitali. 1994. Ikonen-Mafia: Thriller. Berlin: Rütten und Loening. Volkov, Evgeny V. 2017. German Democratic Republic of the 1970s-1980s through the Eyes of Soviet Officers (Oral Stories). Folklore: Electronic Fournal of Folklore 70: 51-70.

Waksberg, Arkadi. 1991. Die sorejetische Mafia: Organisiertes Verbrechen in der Sorojetunion. München: Piper.

Wemicke, C. 1991. Warten auf den Abzug. Zeit, August 23.

Wendt, Alexander. 1994. Scharfe Schätze. Für Waffennarren sind die früheren Standorte der Russen wahre Fundgruben. Focus, October 1.

Witaljew, Witali. 1990. Die rote Mafia: Recherchen im kriminellen Untergrund der USSR. Düsseldorf: Econ.

Woldt, M. 1996. Noch Gruselecken zu verkaufen. Warum kaum jemand die Hinterlassenschaften der russischen Truppen im Osten haben will. Süddeutsche Zeitung, August 9.

Zelizer, Barbie - Tenenboim-Weinblatt, Keren (eds.). 2014. Journalism and Memory. Basingstoke: Palgrave Macmillan 